JAMP: Jurnal Adminitrasi dan Manajemen Pendidikan

Volume 1 Nomor 1 Maret 2018, Hal : 61-69

Tersedia Online di http://journal2.um.ac.id/index.php/jamp/

ISSN $x x x x-x x x x$ (online)

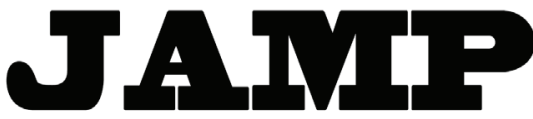

JURNAL ADMINISTRASI DAN MANAJEMEN PENDIDIKAN

\title{
ANALISIS FAKTOR-FAKTOR MOTIVASIONAL PESERTA DIDIK SMA DALAM MENGIKUTI BIMBINGAN BELAJAR DI LUAR SEKOLAH
}

\author{
Nur Amaliyah Hanum \\ Djum Djum Noor Benty \\ Ahmad Yusuf Sobri \\ email: nuramaliyah_hanum@yahoo.co.id \\ Universitas Negeri Malang, Jl. Semarang No. 5 Malang 65145
}

\begin{abstract}
The Analysis of Motivational Factors of High School Students in Attending Course Institutions at Malang City. The purpose of this research is to find new factors, to know the contribution level of each factor, and to find the most dominant factor of high school students in attending course institutions at Malang City. This research uses quantitative approach with descriptive exploratory research design. The research found that there were 9 new factors that is: (a) assessment factor, (b) recognition factor, (c) punishment factor, (d) ability factor, (e) success factor, (f) ridicule factor, (g) social needs factor, (h) appreciation factor, and (i) competition factor.
\end{abstract}

Keywords: motivation of high school students, attending course institutions at Malang City

\begin{abstract}
Abstrak: Tujuan penelitian ini untuk menemukan faktor-faktor baru, mengetahui tingkat kontribusi masing-masing faktor, dan menemukan faktor yang paling dominan pada peserta didik SMA dalam mengikuti bimbingan belajar di luar sekolah Se-Kota Malang. Penelitian ini menggunakan pendekatan kuantitatif dengan rancangan penelitian bersifat deskriptif eksploratori. Hasil penelitian menemukan bahwa terdapat 9 faktor baru yaitu: (a) faktor penilaian, (b) faktor pengakuan, (c) faktor hukuman, (d) faktor kemampuan, (e) faktor keberhasilan, (f) faktor ejekan, (g) faktor kebutuhan sosial, (h) faktor penghargaan, dan (i) faktor persaingan.
\end{abstract}

Kata kunci: motivasi peserta didik SMA, mengikuti bimbingan belajar di luar sekolah

Peserta didik SMA Se-Kota Malang masih banyak yang mengikuti bimbingan belajar di luar sekolah. Meskipun demikian SMA di Kota Malang ada yang menyediakan bimbingan belajar di dalam sekolah dengan nama lain yaitu program intensif belajar. Sekolah seharusnya bisa memberikan layanan bimbingan belajar sebagaimana layanan yang diberikan oleh lembaga bimbingan belajar di luar sekolah. Mencakup tips pembelajaran yang memudahkan pemahaman peserta didik dalam belajar, tips mengerjakan soal dalam waktu cepat, dan tentunya dengan tentor yang cerdas, ramah, dan bersahabat. Hanya faktanya, guru tidak dapat memberikan apa yang menjadi kebutuhan peserta didik.

Berdasarkan hasil penelitian terdahulu dapat disimpulkan, bahwa peserta didik SMA di Kota Malang yang mengikuti pendidikan non formal semacam bimbingan belajar cukup banyak. Menurut UndangUndang RI Nomor 20 Tahun 2003 tentang Sistem Pendidikan Nasional, Pasal 1 (Ayat 12) menjelaskan "pendidikan non formal adalah jalur pendidikan di luar pendidikan formal yang dapat dilaksanakan secara terstruktur dan berjenjang". Pada Undang-Undang RI Nomor 20 Tahun 2003 tentang Sistem Pendidikan Nasional, Pasal 26 (Ayat 4) juga menjelaskan "satuan pendidikan non formal terdiri atas lembaga kursus, lembaga pelatihan, kelompok belajar, pusat kegiatan belajar masyarakat, dan majelis taklim, serta satuan pendidikan yang sejenis". Jadi dapat disimpulkan bahwa lembaga bimbingan belajar merupakan satuan 
pendidikan non formal yang diselenggerakan bagi peserta didik yang memerlukan bekal pengetahuan, keterampilan, kecakapan hidup, dan sikap untuk mengembangkan diri. Disini seharusnya sekolah formal bisa memberikan layanan bimbingan belajar sebagaimana layanan yang diberikan oleh lembaga bimbingan belajar di luar sekolah. Mencakup tips pembelajaran yang memudahkan pemahaman peserta didik dalam belajar, tips mengerjakan soal dalam waktu cepat, dan tentunya dengan tentor yang cerdas, ramah, dan bersahabat. Hanya faktanya, guru tidak dapat memberikan apa yang menjadi kebutuhan peserta didik.

Menurut Peraturan Pemerintah (PP) Nomor 19 Tahun 2005 tentang Standar Nasional Pendidikan, Pasal 19 (dalam Hariyati, dkk, 2010:143) "proses pembelajaran pada satuan pendidikan diselenggarakan secara interaktif, inspiratif, menyenangkan, menantang, memotivasi peserta didik untuk berpartisipasi secara aktif, serta memberikan ruang yang cukup bagi prakarsa, kreatifitas, dan kemandirian sesuai bakat, minat, dan perkembangan fisik serta psikologis peserta didik". Sehingga dapat disimpulkan bahwa dalam pembelajaran guru mempunyai keharusan dalam kenyamanan belajar peserta didiknya karena derajat kualitas guru akan menentukan kualitas peserta didiknya.

Berdasarkan studi pendahuluan peneliti menjelaskan, bahwa terdapat berbagai faktor motivasi peserta didik dalam mengikuti bimbingan belajar di luar sekolah. Sekolah seharusnya memiliki inisiatif sendiri untuk membuka bimbingan belajar di sekolah yaitu dengan merekrut tenaga-tenaga ahli yang profesional seperti yang ditawarkan lembaga bimbingan belajar pada umumnya untuk tentor bimbingan belajar di sekolah. Sehingga peserta didik dapat merasa nyaman saat belajar di sekolah dan merasa cukup dengan mengikuti bimbingan belajar di sekolah. Berdasarkan pernyataan-pernyataan tersebut memperjelas bahwa setiap peserta didik yang mengikuti bimbingan belajar di luar sekolah mempunyai berbagai faktor-faktor yang mendorong mereka mengikuti bimbingan belajar tersebut, baik faktor intrinsik maupun faktor ekstrinsik.

\section{METODE}

Pendekatan penelitian ini menggunakan pendekatan kuantitatif dengan rancangan penelitian bersifat deskriptif eksploratori. Populasi dalam penelitian ini adalah 6 Lembaga Bimbingan Belajar SeKota Malang. Teknik pengambilan sampel yang digunakan dalam penelitian ini adalah quota sampling, sehingga jumlah sampel yang digunakan dalam penelitian ini adalah berjumlah 113 peserta didik SMA yang mengikuti bimbingan belajar di luar sekolah Se-Kota Malang.

Teknik pengumpulan data yang digunakan dalam penelitian ini didasarkan pada konsep dan teori yang melandasi yaitu kuisioner/angket. Penelitian ini menggunakan angket tertutup, dimana responden sudah diberikan jawaban untuk memilihnya. Sedangkan teknik analisis data menggunakan teknik analisis deskriptif dan analisis eksploratori.

\section{HASIL PENELITIAN}

\section{Faktor-Faktor Penyebab Motivasi Peserta Didik SMA dalam Mengikuti Bimbingan Belajar di Luar Sekolah Se-Kota Malang}

Ada dua faktor motivasi peserta didik SMA dalam mengikuti bimbingan belajar di luar sekolah Se-Kota Malang, yakni motivasi secara intrinsik dan ekstrinsik. Peserta didik SMA dalam mengikuti bimbingan belajar di luar sekolah Se-Kota Malang termotivasi secara ekstrinsik lebih banyak daripada yang termotivasi secara intrinsik. Hasil dari penelitian ini mengidentifikasi, bahwa peserta didik yang termotivasi secara intrinsik sebesar $24 \%$ dan sebesar $76 \%$ termotivasi secara ekstrinsik, dengan jumlah skor faktor intrinsik sebanyak 4009 poin dari 9 butir pernyataan dan jumlah skor faktor ekstrinsik sebanyak 12394 poin dari 37 butir pernyataan. Hal ini menandakan, bahwa peserta didik SMA dalam mengikuti bimbingan belajar di luar sekolah Se-Kota Malang termotivasi karena banyaknya alasan dari faktor eksrinsik seperti angka, kredit, ijazah, tingkatan, hadiah, medali, pertentangan dan persaingan, sarkasme, dan ejekan. 
Hasil dari analisis juga memperoleh Kaiser Meyer Olkin (KMO) Measure of Sampling Adequacy sebesar 0,772 dan Bartlett's Test of Sphericity sebesar 3353,862 dengan signifikan sebesar 0,000. Apabila melihat nilai KMO yang lebih besar dari $>0,5$ maka mempunyai arti bahwa analisis faktor tepat. Berdasarkan jumlah koefisien eigen value sebesar $\geq 1$ dapat teridentifikasi sebanyak 9 faktor dan persentase komulatifnya sebesar $72,713 \%$. Faktor-faktor motivasi baru yang ditemukan dalam penelitian ini antara lain: (a) faktor penilaian, (b) faktor pengakuan, (c) faktor hukuman, (d) faktor kemampuan, (e) faktor keberhasilan, (f) faktor ejekan, (g) faktor kebutuhan sosial, (h) faktor penghargaan, dan (i) faktor persaingan.

\section{Tingkat Kontribusi Masing-Masing Faktor Penyebab Peserta Didik SMA Dalam Mengikuti Bimbingan Belajar di Luar Sekolah Se-Kota Malang}

Perhitungan akan tingkat kontribusi masing-masing faktor penyebab peserta didik SMA dalam mengikuti bimbingan belajar di luar sekolah Se-Kota Malang dengan menggunakan analisis deskripsi. Hal ini dikarenakan untuk mengetahui kondisi masing-masing faktor.

\section{Faktor Penilaian}

Berdasarkan rumus menentukan panjang kelas interval, pada faktor penilaian diperoleh hasil sebesar 11,405. Berdasarkan distribusi frekuensi faktor penilaian menunjukkan, bahwa peserta didik SMA yang termotivasi mengikuti bimbingan belajar di luar sekolah Se-Kota Malang tergolong tinggi sebanyak 27 peserta didik atau sebesar 23,89\%. Peserta didik yang tergolong dalam kategori sedang sebanyak 61 peserta didik atau sebesar $53,98 \%$. Sementara itu peserta didik yang tergolong dalam kategori rendah sebanyak 25 peserta didik atau sebesar 22,13\%. Demikian dapat disimpulkan, bahwa persentase faktor penilaian pada peserta didik SMA yang mengikuti bimbingan belajar di luar sekolah Se-Kota Malang dalam kategori ‘sedang', yakni sebanyak 61 peserta didik atau sebesar 53,98\%.

\section{Faktor Pengakuan}

Berdasarkan rumus menentukan panjang kelas interval diperoleh hasi sebesar 5,495. Berdasarkan distribusi frekuensi faktor pengakuan menunjukkan, bahwa peserta didik SMA yang termotivasi mengikuti bimbingan belajar di luar sekolah Se-Kota Malang tergolong tinggi sebanyak 28 peserta didik atau sebesar $24,78 \%$. Peserta didik yang tergolong dalam kategori sedang sebanyak 66 peserta didik atau sebesar 58,41\%. Sementara itu peserta didik yang tergolong dalam kategori rendah sebanyak 19 peserta didik atau sebesar $16,81 \%$. Jadi persentase faktor pengakuan pada peserta didik SMA yang mengikuti bimbingan belajar di luar sekolah Se-Kota Malang dalam kategori 'sedang', yakni sebanyak 66 peserta didik atau sebesar $58,41 \%$.

\section{Faktor Hukuman}

Berdasarkan rumus menentukan panjang kelas interval diperoleh hasi sebesar 4,354. Berdasarkan distribusi frekuensi faktor hukuman menunjukkan, bahwa peserta didik SMA yang termotivasi mengikuti bimbingan belajar di luar sekolah Se-Kota Malang tergolong tinggi sebanyak 10 peserta didik atau sebesar $8,85 \%$. Peserta didik yang tergolong dalam kategori sedang sebanyak 51 peserta didik atau sebesar $45,13 \%$. Sementara itu peserta didik yang tergolong dalam kategori rendah sebanyak 52 peserta didik atau sebesar 46,02\%. Demikian dapat disimpulkan, bahwa persentase faktor hukuman pada peserta didik SMA yang mengikuti bimbingan belajar di luar sekolah Se-Kota Malang dalam kategori 'rendah', yakni sebanyak 52 peserta didik atau sebesar $46,02 \%$.

\section{Faktor Kemampuan}

Berdasarkan rumus menentukan panjang kelas interval diperoleh hasi sebesar 6,603. Berdasarkan distribusi frekuensi faktor kemampuan menunjukkan, bahwa peserta didik SMA yang termotivasi mengikuti bimbingan belajar di luar sekolah Se-Kota Malang tergolong tinggi sebanyak 46 peserta didik atau sebesar $40,71 \%$. Peserta didik yang tergolong dalam kategori sedang sebanyak 63 peserta didik atau sebesar $55,75 \%$. Sementara itu peserta didik yang tergolong dalam kategori rendah sebanyak 4 peserta didik atau sebesar 3,54\%. Demikian dapat disimpulkan, bahwa persentase faktor kemampuan pada peserta didik SMA yang mengikuti bimbingan belajar di luar sekolah Se-Kota Malang dalam 
kategori 'sedang', yakni sebanyak 63 peserta didik atau sebesar 55,75\%.

\section{Faktor Keberhasilan}

Berdasarkan rumus menentukan panjang kelas interval diperoleh hasi sebesar 4,000. Berdasarkan distribusi frekuensi faktor keberhasilan menunjukkan, bahwa peserta didik SMA yang termotivasi mengikuti bimbingan belajar di luar sekolah Se-Kota Malang tergolong tinggi sebanyak 41 peserta didik atau sebesar $36,28 \%$. Peserta didik yang tergolong dalam kategori sedang sebanyak 61 peserta didik atau sebesar 53,98\%. Sementara itu peserta didik yang tergolong dalam kategori rendah sebanyak 11 peserta didik atau sebesar 9,74\%. Demikian dapat disimpulkan, bahwa persentase faktor keberhasilan pada peserta didik SMA yang mengikuti bimbingan belajar di luar sekolah Se-Kota Malang dalam kategori 'sedang', yakni sebanyak 61 peserta didik atau sebesar 53,98\%.

\section{Faktor Ejekan}

Berdasarkan rumus menentukan panjang kelas interval diperoleh hasi sebesar 3,395. Berdasarkan distribusi frekuensi faktor ejekan menunjukkan, bahwa peserta didik SMA yang termotivasi mengikuti bimbingan belajar di luar sekolah Se-Kota Malang tergolong tinggi sebanyak 12 peserta didik atau sebesar $10,62 \%$. Peserta didik yang tergolong dalam kategori sedang sebanyak 67 peserta didik atau sebesar 59,29\%. Sementara itu peserta didik yang tergolong dalam kategori rendah sebanyak 34 peserta didik atau sebesar 30,09\%. Demikian dapat disimpulkan, bahwa persentase faktor ejekan pada peserta didik SMA yang mengikuti bimbingan belajar di luar sekolah Se-Kota Malang dalam kategori ‘sedang', yakni sebanyak 67 peserta didik atau sebesar 59,29\%.

\section{Faktor Kebutuhan Sosial}

Berdasarkan rumus menentukan panjang kelas interval diperoleh hasi sebesar 4,677. Berdasarkan distribusi frekuensi faktor kebutuhan sosial menunjukkan, bahwa peserta didik SMA yang termotivasi mengikuti bimbingan belajar di luar sekolah Se-Kota Malang tergolong tinggi sebanyak 23 peserta didik atau sebesar $20,35 \%$. Peserta didik yang tergolong dalam kategori sedang sebanyak 54 peserta didik atau sebesar $47,79 \%$. Sementara itu peserta didik yang tergolong dalam kategori rendah sebanyak 36 peserta didik atau sebesar 31,86\%. Demikian dapat disimpulkan, bahwa persentase faktor kebutuhan sosial pada peserta didik SMA yang mengikuti bimbingan belajar di luar sekolah Se-Kota Malang dalam kategori 'sedang', yakni sebanyak 54 peserta didik atau sebesar 47,79\%.

\section{Faktor Penghargaan}

Berdasarkan rumus menentukan panjang kelas interval diperoleh hasi sebesar 2,386. Berdasarkan distribusi frekuensi faktor penghargaan menunjukkan, bahwa peserta didik SMA yang termotivasi mengikuti bimbingan belajar di luar sekolah Se-Kota Malang tergolong tinggi sebanyak 29 peserta didik atau sebesar $25,66 \%$. Peserta didik yang tergolong dalam kategori sedang sebanyak 51 peserta didik atau sebesar $45,13 \%$. Sementara itu peserta didik yang tergolong dalam kategori rendah sebanyak 33 peserta didik atau sebesar 29,21\%. Demikian dapat disimpulkan, bahwa persentase faktor penghargaan pada peserta didik SMA yang mengikuti bimbingan belajar di luar sekolah Se-Kota Malang dalam kategori 'sedang', yakni sebanyak 51 peserta didik atau sebesar 45,13\%.

\section{Faktor Persaingan}

Berdasarkan rumus menentukan panjang kelas interval diperoleh hasi sebesar 2,078. Berdasarkan distribusi frekuensi faktor persaingan menunjukkan, bahwa peserta didik SMA yang termotivasi mengikuti bimbingan belajar di luar sekolah Se-Kota Malang tergolong tinggi sebanyak 31 peserta didik atau sebesar $27,43 \%$. Peserta didik yang tergolong dalam kategori sedang sebanyak 54 peserta didik atau sebesar $47,79 \%$. Sementara itu peserta didik yang tergolong dalam kategori rendah sebanyak 28 peserta didik atau sebesar $24,78 \%$. Demikian dapat disimpulkan, bahwa persentase faktor persaingan pada peserta didik SMA yang mengikuti bimbingan belajar di luar sekolah Se-Kota Malang dalam kategori 'sedang', yakni sebanyak 54 peserta didik atau sebesar 47,79\%. 


\section{Faktor Paling Dominan Pada Peserta Didik SMA Dalam Mengikuti Bimbingan Belajar di Luar Sekolah Se-Kota Malang}

Faktor penilaian memiliki tingkat variansi yang paling tinggi terhadap motivasi peserta didik SMA dalam mengikuti bimbingan belajar di luar sekolah Se-Kota Malang sebesar 16,141\%. Sehingga dapat disimpulkan bahwa faktor paling dominan yang memotivasi peserta didik SMA dalam mengikuti bimbingan belajar di luar sekolah Se-Kota Malang adalah faktor penilaian dengan persentase sebesar 22\%.

\section{PEMBAHASAN}

\section{Faktor-Faktor Penyebab Motivasi Peserta Didik SMA dalam Mengikuti Bimbingan Belajar di Luar Sekolah Se-Kota Malang}

Hasil analisis faktor ditemukan 9 faktor baru yang memotivasi peserta didik SMA dalam mengikuti bimbingan belajar di luar sekolah Se-Kota Malang. Adapun kesembilan faktor baru, yaitu (1) faktor penilaian, (2) faktor pengakuan, (3) faktor hukuman, (4) faktor kemampuan, (5) faktor keberhasilan, (6) faktor ejekan, (7) faktor kebutuhan sosial, (8) faktor penghargaan, (9) faktor persaingan.

\section{Faktor Penilaian}

Faktor ini terwakili oleh 10 butir pernyataan dengan nilai variance sebesar $16,141 \%$. Kemudian faktor ini diberi konsep baru dengan nama faktor penilaian. Faktor ini sesuai dengan teori yang diungkapkan oleh Sardiman (2001:90) bahwa nilai dalam hal ini sebagai simbol dari nilai kegiatan belajarnya. Banyak peserta didik belajar, yang utama justru untuk mencapai angka/nilai yang baik. Sehingga peserta didik biasanya yang dikejar adalah nilai ulangan atau nilai-nilai pada raport angkanya baik-baik. Peraturan Mendikbud RI Nomor 3 Tahun 2013 tentang Kriteria Kelulusan Peserta Didik dari Satuan Pendidikan dan Penyelenggaraan Ujian Sekolah/Madrasah/Pendidikan Kesetaraan dan Ujian Nasional, Pasal 1 yaitu bahwa kriteria kelulusan adalah persyaratan pencapaian minimal untuk dinyatakan lulus. Faktor ini berhubungan dengan pencapaian kelulusan sekolah. Adanya faktor ini peserta didik SMA akan berusaha semaksimal mungkin untuk mencapai tujuan yang diinginkan.

\section{Faktor Pengakuan}

Faktor ini terwakili oleh 5 butir pernyataan dengan nilai variance sebesar 11,882\%. Kemudian faktor ini diberi konsep baru dengan nama faktor pengakuan. Faktor ini sesuai dengan teori kebutuhan menurut Maslow (dalam Siagian, 1990:131-133) yaitu sebagai makhluk sosial seorang peserta didik membutuhkan kebutuhan akan perasaan diterima oleh orang lain dimana ia hidup dan bekerja (sense of belonging), kebutuhan akan perasaan dihormati karena setiap manusia merasa dirinya penting (sense of importance), kebutuhan akan perasaan maju dan tidak gagal (sense of achievement), kebutuhan akan perasaan "ikut serta" (sense of participation), dan itu semua selalu tergantung pada prestasi atau keberhasilan. Lima hierarkhi menurut Sobri, dkk (2009:25) salah satunya bahwa seorang peserta didik membutuhkan kebutuhan sosial (persamaan kelompok), seperti: kegiatan sosial, pengakuan dari pihak lain, cinta. Semakin tinggi prestasi seorang peserta didik maka nilai penghargaan orang lain semakin tinggi. Sehingga dapat disimpulkan bahwa seseorang membutuhkan rasa ingin maju dan dihargai/diakui oleh orang lain.

\section{Faktor Hukuman}

Faktor ini terwakili oleh 4 butir pernyataan dengan nilai variance sebesar 9,791\%. Kemudian faktor ini diberi konsep baru dengan nama faktor hukuman. Faktor ini sesuai dengan teori yang diungkapkan oleh Sardiman (2001:92) menjelaskan bahwa hukuman sebagai reinforcement yang negatif tetapi kalau diberikan secara tepat dan bijak bisa menjadi alat motivasi. Oleh karena itu guru harus memahami prinsip-prinsip pemberian hukuman. Menurut Suwarno (1992:115) ada bermacam-macam teori tentang hukuman ini, salah satunya yaitu menghukum supaya keadaan tidak diulangi lagi, teori ini dapat digunakan dalam pendidikan. Oleh karena itu dapat disimpulkan bahwa tujuan guru memberikan hukuman tersebut tidak lain agar peserta didik merasa jera, sehingga menumbuhkan motivasinya dalam 
meningkatkan prestasi belajarnya diantaranya dengan mengikuti bimbingan belajar di luar sekolah.

\section{Faktor Kemampuan}

Faktor ini terwakili oleh 6 butir pernyataan dengan nilai variance besar 8,395\%. Kemudian faktor ini diberi konsep baru dengan nama faktor kemampuan. Faktor ini sesuai dengan teori yang diungkapkan oleh Sukardi (1987:45) bahwa kemampuan atau bakat merupakan suatu kondisi, suatu kualitas yang dimiliki individu yang memungkinkan individu itu untuk berkembang pada masa mendatang. Jadi dapat disimpulkan bahwa bakat tidak bisa dipengaruhi lingkungan meskipun ada pengaruh lingkungan akan sangat kecil. Jadi bakat sifatnya potensial dari dalam diri seseorang yang berhubungan dengan prestasi.

\section{Faktor Keberhasilan}

Faktor ini terwakili oleh 3 butir pernyataan dengan nilai variance sebesar 6,512\%. Kemudian faktor ini diberi konsep baru dengan nama faktor keberhasilan. Faktor ini sesuai dengan teori McClelland dikenal dengan teori kebutuhan untuk mencapai prestasi atau Need for Acievement yaitu motivasi peserta didik SMA dalam mengikuti bimbingan belajar berbeda-beda sesuai dengan kekuatan kebutuhan mereka akan prestasinya. Murray (dalam Sudrajat, 2008) menyatakan kebutuhan akan prestasi tersebut salah satunya adalah sebagai keinginan untuk mencapai performa puncak untuk diri sendiri.

\section{Faktor Ejekan}

Faktor ini terwakili oleh 3 butir pernyataan dengan nilai variance sebesar 6,037\%. Kemudian faktor ini diberi konsep baru dengan nama faktor ejekan. Faktor ini sesuai dengan teori Hasibuan dan Moedjiono (1988:56) yaitu ejekan disini merupakan sama halnya dengan hukuman, hanya saja hukuman lebih diartikan secara luas. Hamalik (2013:112) dalam motivasi belajar siswa menyatakan, bahwa yang bersifat negatif salah satunya yaitu ejekan (ridicule). Jadi dapat disimpulkan bahwa ejekan yang diberikan kepada peserta didik merupakan bentuk reinforcement negative, yaitu sesuatu yang dapat memperlemah timbulnya respon atau memperkecil kemungkinan hubungan stimulus-respon. Reinforcement negative dapat digunakan apabila memang dibutuhkan.

\section{Faktor Kebutuhan Sosial}

Faktor ini terwakili oleh 5 butir pernyataan dengan nilai variance sebesar 6,001\%. Kemudian faktor ini diberi konsep baru dengan nama faktor kebutuhan sosial. Faktor ini sesuai dengan teori Maslow (dalam Hamalik, 2013:109-110) yang menyatakan bahwa kebutuhan manusia sifatnya bertingkat-tingkat. Pemuasan terhadap tingkat kebutuhan tertentu dapat dilakukan jika tingkat kebutuhan sebelumnya telah mendapat pemuasan. Kebutuhan-kebutuhan itu salah satunya ialah kebutuhan sosial, yang terdiri dari kebutuhan perasaan untuk diterima oleh orang lain, perasaan dihormati, kebutuhan untuk berprestasi, dan kebutuhan perasaan berpartisipasi. Lima hierarkhi menurut Sobri, dkk, (2009:25) salah satunya menjelaskan bahwa kebutuhan sosial (persamaan kelompok), seperti: kegiatan sosial, pengakuan dari pihak lain, cinta. peserta didik SMA mengikuti bimbingan belajar di luar sekolah salah satunya adalah untuk memenuhi kebutuhan sosialnya, dimana mereka membutuhkan rasa penerimaan dari orang lain, rasa ingin dihormati orang lain, rasa ingin berprestasi dan rasa ingin berpartisipasi.

\section{Faktor Penghargaan}

Faktor ini terwakili oleh 2 butir pernyataan dengan nilai variance sebesar 4,002\%. Kemudian faktor ini diberi konsep baru dengan nama faktor penghargaan. Hadiah merupakan sebuah reward, yaitu suatu penghargaan yang diberikan kepada seseorang yang memiliki kelebihan seperti peserta didik yang mempunyai prestasi, berperilaku baik, rajin, tekun, dan sebagainya. Indrakusuma (1973:147) menjelaskan penghargaan merupakan hadiah terhadap hasil-hasil yang baik dari anak dalam proses pendidikan. Penghargaan merupakan hal yang menggembirakan bagi anak, dan dapat menjadi pendorong bagi belajarnya. Indrakusuma (1973:159-160) menyimpulkan bahwa terdapat berbagai jenis penghargaan dan yang dimaksud hadiah disini merupakan penghargaan berbentuk benda/barang/uang. Pemberian reward juga dapat membesarkan kemungkinan bertambah giatnya usaha untuk mempertinggi/memperbaiki prestasi, maka kegiatan pemberian reward ini sangat penting untuk meningkatkan motivasi peserta didik dalam belajar. 


\section{Faktor Persaingan}

Faktor ini terwakili oleh 2 butir pernyataan dengan nilai variance sebesar 3,951\%. Kemudian faktor ini diberi konsep baru dengan nama faktor persaingan. Faktor ini sesuai dengan teori Sardiman (2001:91) menjelaskan bahwa saingan atau kompetisi dapat digunakan sebagai alat motivasi untuk mendorong belajar peserta didik. Persaingan, baik persaingan individual maupun persaingan kelompok dapat meningkatkan prestasi belajar peserta didik.

\section{Tingkat Kontribusi Masing-Masing Faktor Penyebab Peserta Didik SMA Dalam Mengikuti Bimbingan Belajar di Luar Sekolah Se-Kota Malang}

Berdasarkan hasil analisis ditemukan 9 faktor baru yang memotivasi peserta didik SMA dalam mengikuti bimbingan belajar di luar sekolah Se-Kota Malang. Adapun kesembilan faktor baru, yaitu (1) faktor penilaian, (2) faktor pengakuan, (3) faktor hukuman, (4) faktor kemampuan, (5) faktor keberhasilan, (6) faktor ejekan, (7) faktor kebutuhan sosial, (8) faktor penghargaan, (9) faktor persaingan.

\section{Faktor Penilaian}

Analisis data faktor penilaian pada peserta didik SMA yang mengikuti bimbingan belajar di luar sekolah Se-Kota Malang dalam kategori ‘sedang', yakni sebanyak 61 peserta didik atau sebesar 53,98\%. Berdasarkan pendapat tersebut, peserta didik SMA yang mengikuti bimbingan belajar di luar sekolah Se-Kota Malang sudah memenuhi indikator penilaian. Arikunto (1993:1) yang membedakan antara pengukuran, penilaian, dan evaluasi yaitu bahwa mengukur adalah membandingkan sesuatu dengan satu ukuran.

\section{Faktor Pengakuan}

Analisis data faktor pengakuan pada peserta didik SMA yang mengikuti bimbingan belajar di luar sekolah Se-Kota Malang dalam kategori 'sedang', yakni sebanyak 66 peserta didik atau sebesar 58,41\%. Berdasarkan pendapat tersebut, peserta didik SMA yang mengikuti bimbingan belajar di luar sekolah Se-Kota Malang sudah memenuhi indikator pengakuan. Menurut Kamus Besar Bahasa Indonesia, pengakuan adalah proses, cara, perbuatan mengaku atau mengakui. Dalam faktor pengakuan ini, peserta didik SMA merasa termotivasi untuk mengikuti bimbingan belajar ketika dirinya menunjukkan tujuan yang hendak dicapainya.

\section{Faktor Hukuman}

Analisis data faktor hukuman pada peserta didik SMA yang mengikuti bimbingan belajar di luar sekolah Se-Kota Malang dalam kategori 'rendah', yakni sebanyak 52 peserta didik atau sebesar 46,02\%. Berdasarkan pendapat tersebut, peserta didik SMA yang mengikuti bimbingan belajar di luar sekolah Se-Kota Malang belum memenuhi indikator hukuman. Menurut Suwarno (1992:115) ada bermacammacam teori tentang hukuman ini, yaitu 1) menghukum karena kesalahan (dosa), teori ini tidak dapat digunakan dalam pendidikan, dan 2) menghukum supaya keadaan tidak diulangi lagi, teori ini dapat digunakan dalam pendidikan.

\section{Faktor Kemampuan}

Analisis data faktor kemampuan pada peserta didik SMA yang mengikuti bimbingan belajar di luar Sekolah Se-Kota Malang dalam kategori 'sedang', yakni sebanyak 63 peserta didik atau sebesar $55,75 \%$. Berdasarkan pendapat tersebut, peserta didik SMA yang mengikuti bimbingan belajar di luar sekolah Se-Kota Malang sudah memenuhi indikator kemampuan. Menurut Maslow berpendapat, bahwa manusia memiliki lima tingkat kebutuhan yang mendasar, yaitu: kebutuhan akan penghargaan, termasuk kebutuhan dihargai karena prestasi, kemampuan, status dan pangkat. Sesuai pendapat ini, peserta didik SMA harus memiliki kemampuan yang mendukung untuk mencapai tujuan yang hendak dicapainya.

\section{Faktor Keberhasilan}

Analisis data faktor keberhasilan pada peserta didik SMA yang mengikuti bimbingan belajar di luar sekolah Se-Kota Malang dalam kategori ‘sedang', yakni sebanyak 61 peserta didik atau sebesar 53,98\%. 
Berdasarkan pendapat tersebut, peserta didik SMA yang mengikuti bimbingan belajar di luar sekolah Se-Kota Malang sudah memenuhi indikator keberhasilan. Teori kebutuhan menurut Maslow (dalam Siagian, 1990:131-133) menggolongkan kebutuhan-kebutuhan manusia kepada lima tingkat kebutuhan (five hierarchy of needs) salah satunya yaitu kebutuhan akan perasaan maju dan tidak gagal (sense of achievement). Faktor ini juga sesuai dengan teori Heriberg yang mengemukakan, bahwa peserta didik SMA yang mengikuti bimbingan belajar di luar sekolah termotivasi akan kebutuhan prestasi.

\section{Faktor Ejekan}

Analisis data faktor ejekan pada peserta didik SMA yang mengikuti bimbingan belajar di luar sekolah Se-Kota Malang dalam kategori 'sedang', yakni sebanyak 67 peserta didik atau sebesar 59,29\%. Hamalik (2013:112) dalam motivasi belajar peserta didik menyatakan, yang bersifat negatif ialah sarkasme, ejekan (ridicule), dan hukuman. Ejekan merupakan bentuk olokan yang dilakukan seseorang yang langsung mengarah pada maksudnya atau bertujuan untuk mengejek. Berdasarkan hal tersebut, ejekan yang dilakukan orang lain dalam dunia pendidikan baik itu guru maupun teman sesama peserta didik membuat peserta didik SMA termotivasi untuk mengikuti bimbingan belajar di luar sekolah SeKota Malang guna memperbaiki/mencapai nilai yang lebih baik lagi.

\section{Faktor Kebutuhan Sosial}

Analisis data faktor kebutuhan sosial pada peserta didik SMA yang mengikuti bimbingan belajar di luar sekolah Se-Kota Malang dalam kategori 'sedang', yakni sebanyak 54 peserta didik atau sebesar 47,79\%. Lima hierarkhi menurut Sobri, dkk, (2009:25) salah satunya menjelaskan bahwa kebutuhan sosial (persamaan kelompok), seperti: kegiatan sosial, pengakuan dari pihak lain, cinta. Kebutuhan sosial bermacam-macam, peserta didik membutuhkan kebutuhan sosial untuk mengembangkan dirinya.

\section{Faktor Penghargaan}

Analisis data faktor penghargaan pada peserta didik SMA yang mengikuti bimbingan belajar di luar sekolah Se-Kota Malang dalam kategori 'sedang', yakni sebanyak 51 peserta didik atau sebesar 45,13\%. Indrakusuma (1973:147) menyatakan penghargaan merupakan hadiah terhadap hasil-hasil yang baik dari anak dalam proses pendidikan. Penghargaan merupakan hal yang menggembirakan bagi anak, dan dapat menjadi pendorong bagi belajarnya.

\section{Faktor Persaingan}

Analisis data faktor persaingan pada peserta didik SMA yang mengikuti bimbingan belajar di luar sekolah Se-Kota Malang dalam kategori ‘sedang', yakni sebanyak 54 peserta didik atau sebesar 47,79\%. Persaingan juga merupakan salah satu faktor eksternal peserta didik dalam mengikuti bimbingan belajar di luar sekolah yang saat ini semakin ketat dengan adanya perkembangan teknologi dan sebagainya.

\section{Faktor Paling Dominan Pada Peserta Didik SMA Dalam Mengikuti Bimbingan Belajar di Luar Sekolah Se-Kota Malang}

Faktor ini memiliki nilai egien value yang besar dibanding faktor lainnya sebesar 23,928 dan variance sebesar $16,141 \%$. Selain itu, faktor penilaian termasuk dalam kategori 'sedang' yakni sebanyak 61 peserta didik atau sebesar 53,98\%. Sardiman (2001:90) bahwa nilai dalam hal ini sebagai simbol dari nilai kegiatan belajarnya. Banyak peserta didik belajar, yang utama justru untuk mencapai angka/nilai yang baik. Berdasarkan pendapat tersebut, peserta didik SMA dalam mengikuti bimbingan belajar di luar sekolah Se-Kota Malang sudah memenuhi indikator penilaian.

\section{KESIMPULAN DAN SARAN}

\section{Kesimpulan}

Berdasarkan hasil dan pembahasan penelitian dapat disimpulkan bahwa: (1) penelitian ini menemukan faktor-faktor yang menyebabkan motivasi peserta didik SMA dalam mengikuti bimbingan belajar di luar sekolah Se-Kota Malang, yaitu (a) faktor penilaian, (b) faktor pengakuan, (c) faktor hukuman, 
(d) faktor kemampuan, (e) faktor keberhasilan, (f) faktor ejekan, (g) faktor kebutuhan sosial, (h) faktor penghargaan, (i) faktor persaingan; (2) tingkat kontribusi masing-masing faktor motivasi peserta didik SMA dalam mengikuti bimbingan belajar di luar sekolah Se-Kota Malang, yaitu (a) faktor penilaian, (b) faktor pengakuan, (c) faktor hukuman, (d) faktor kemampuan, (e) faktor keberhasilan, (f) faktor ejekan, (g) faktor kebutuhan sosial, (h) faktor penghargaan, dan (i) faktor persaingan; (3) faktor motivasi peserta didik SMA yang paling dominan mengikuti bimbingan belajar di luar sekolah Se-Kota Malang adalah faktor penilaian. Hal ini dapat dilihat dari nilai eigen value tertinggi dari faktor lainnya. Indikator faktor penilaian meliputi, nilai-nilai sekolah yang tidak memuaskan, prestasi kurang baik, dan mendapat teguran dari orangtua dan guru.

\section{Saran}

Saran yang dapat diberikan antara lain: (1) bagi Ketua Jurusan Administrasi Pendidikan, dapat menyebarluaskan lulusan administrasi pendidikan yang mampu mengaplikasikan ilmu pengetahuan manajemen pendidikan terutama menekankan pada pengetahuan dan pemahaman supervisi pendidikan sehingga dapat mencetak guru-guru yang menyenangkan, ramah, penyabar, bersahabat, dan tentunya guru yang cerdas bagi peserta didik di sekolah; (2) bagi Kepala SMA Se-Kota Malang, dapat lebih menekankan pada peningkatan kualitas pembelajaran di sekolah dengan guru-guru yang menyenangkan, ramah, penyabar, bersahabat, dan tentunya guru yang cerdas dimana ini merupakan bentuk pelayanan Lembaga Bimbingan Belajar (LBB) yang menjadikan peserta didik betah dalam belajar; (3) bagi Lembaga Bimbingan Belajar di Luar Sekolah Se-Kota Malang, dapat membantu peserta didik dalam menekankan dan meningkatkan motivasi belajar peserta didik di sekolah; (4) bagi peneliti lain, penelitian ini hanya meneliti peserta didik SMA dan diharapkan peneliti lain dapat meneliti seluruh tingkatan sekolah seperti motivasi peserta didik SD/MI, SMP/MTs, dan SMA/MA/SMK dalam mengikuti bimbingan belajar di luar sekolah Se-Kota Malang dan menyempurnakan penelitian selanjutnya.

\section{DAFTAR RUJUKAN}

Arikunto, S. 1993c. Dasar-Dasar Evaluasi Pendidikan. Jakarta: Bumi Aksara.

Hamalik, O. 2013. Kurikulum dan Pembelajaran. Jakarta: Bumi Aksara.

Hariyati, dkk. 2010. Aktualisasi Kepemimpinan Kepala Sekolah Dalam Implementasi Lesson Study Berbasis Sekolah. Jurnal Manajemen Pendidikan, 23 (2): 143.

Hasibuan, J.J., dan Moedjiono. 1988. Proses Belajar Mengajar. Bandung: Remadja Karya.

Indrakusuma, A. D. 1973. Pengantar Ilmu Pendidikan. Surabaya: Usaha Nasional.

Kamus Besar Bahasa Indonesia (KBBI): Edisi Kedua. 1991. Balai Pustaka: Departemen Pendidikan dan Kebudayaan.

Peraturan Mendikbud RI Nomor 3 Tahun 2013 tentang Kriteria Kelulusan Peserta Didik dari Satuan Pendidikan dan Penyelenggaraan Ujian Sekolah/Madrasah/Pendidikan Kesetaraan dan Ujian Nasional. Kepala Biro Hukum dan Organisasi Kementrian Pendidikan dan Kebudayaan. (Online), (http://bsnp-indonesia.org/wpcontent/uploads/2013/02/Permen-no-3-tahun-2013.pdf), diakses 25 April 2017.

Sardiman, A., M. 2001. Interaksi \& Motivasi Belajar Mengajar. Jakarta: PT Raja Grafindo Persada.

Siagian, S., P. 1990. Filsafat Administrasi. Jakarta: Haji Masagung.

Sobri, dkk. 2009. Pengelolaan Pendidikan. Yogyakarta: Multi Pressindo.

Sudrajat, A. 2008. Teori-teori Motivasi, (Online), (http://akhmadsudrajat.wordpress.com/2008/02/06/teori-teorimotivasi/), diakses 12 Maret 2016.

Sukardi, D., K. 1987. Bimbingan Karir di Sekolah-sekolah. Jakarta: Ghalia Indonesia.

Suwarno. 1992. Pengantar Ilmu Pendidikan. Jakarta: PT Rineka Cipta.

Undang-Undang RI No. 20 Tahun 2003 tentang Sistem Pendidikan Nasional. (Online), (https://kemenag.go.id/file/ dokumen/UU2003.pdf), diakses 14 Agustus 2017. 